Purdue University

Purdue e-Pubs

CTRC Research Publications

Cooling Technologies Research Center

2009

\title{
A Composite Heat Transfer Correlation for Saturated Flow Boiling in Small Channels
}

S S. Bertsch

E A. Groll

S V. Garimella

Purdue University, sureshg@purdue.edu

Follow this and additional works at: http://docs.lib.purdue.edu/coolingpubs

Bertsch, S S.; Groll, E A.; and Garimella, S V., "A Composite Heat Transfer Correlation for Saturated Flow Boiling in Small Channels" (2009). CTRC Research Publications. Paper 113.

http://dx.doi.org/10.1016/j.ijheatmasstransfer.2008.10.022

This document has been made available through Purdue e-Pubs, a service of the Purdue University Libraries. Please contact epubs@purdue.edu for additional information. 


\title{
A Composite Heat Transfer Correlation for Saturated Flow Boiling in Small Channels
}

\author{
Stefan S. Bertsch ${ }^{1,2}$, Eckhard A. Groll ${ }^{1,2}$, Suresh V. Garimella ${ }^{2, \dagger}$ \\ ${ }^{1}$ Ray W. Herrick Laboratories and ${ }^{2}$ Cooling Technologies Research Center \\ School of Mechanical Engineering, Purdue University \\ 585 Purdue Mall, West Lafayette, IN 47907-2088 USA
}

\begin{abstract}
Recent reviews of flow boiling heat transfer in small tubes and channels have highlighted the need for predictive correlations that are applicable over a wide range of parameters and across different studies. A composite correlation is developed in the present work which includes nucleate boiling and convective heat transfer terms while accounting for the effect of bubble confinement in small channels. The correlation is developed from a database of 3899 data points from 14 studies in the literature covering 12 different wetting and non-wetting fluids, hydraulic diameters ranging from 0.16 to $2.92 \mathrm{~mm}$, and confinement numbers from 0.3 to 4.0 . The mass fluxes included in the database range from 20 to $3000 \mathrm{~kg} \mathrm{~m}^{-2} \mathrm{~s}^{-1}$, the heat fluxes from 0.4 to 115 $\mathrm{W} \mathrm{cm}{ }^{-2}$, the vapor qualities from 0 to 1 , and the saturation temperatures from -194 to $97^{\circ} \mathrm{C}$. While some of the data sets show opposing trends with respect to some parameters, a mean absolute error of less than $30 \%$ is achieved with the proposed correlation.
\end{abstract}

Keywords: microchannel, minichannel, flow boiling, heat transfer, correlation

\footnotetext{
* Submitted for publication in International Journal of Heat and Mass Transfer, June 2008, and in revised form, October 2008

${ }^{\dagger}$ To whom correspondence should be addressed: sureshg@purdue.edu, 765-494-5621
} 


\section{Nomenclature}

$\mathrm{a}, \mathrm{b}$ empirical constants in flow boiling equation

Co confinement number $\mathrm{Co}=\left(\frac{\sigma}{\mathrm{g} \cdot\left(\rho_{l}-\rho_{\mathrm{v}}\right) \cdot \mathrm{D}_{\mathrm{h}}{ }^{2}}\right)^{1 / 2}$

D diameter, $\mathrm{m}$

F enhancement factor

g gravitational acceleration, $\mathrm{m} \mathrm{s}^{-2}$

G mass flux, $\mathrm{kg} \mathrm{m}^{-2} \mathrm{~s}^{-1}$

$\mathrm{h}$ heat transfer coefficient, $\mathrm{W} \mathrm{m}^{-2} \mathrm{~K}^{-1}$

$\mathrm{H}$ channel height, $\mathrm{m}$

$\mathrm{k}$ thermal conductivity, $\mathrm{W} \mathrm{m}^{-1} \mathrm{~K}^{-1}$

$\mathrm{L} \quad$ length in flow direction, $\mathrm{m}$

M molecular mass of the fluid, $\mathrm{kg} \mathrm{kmol}^{-1}$

MAE mean absolute error, $\%$

$\mathrm{n}$ number of data points

$\mathrm{N}$ number of microchannels

$\mathrm{P}$ pressure, $\mathrm{Pa}$

$\mathrm{P}_{\mathrm{r}} \quad$ reduced pressure

Pr Prandtl number

$\mathrm{q}^{\prime \prime} \quad$ heat flux, $\mathrm{W} \mathrm{m}^{-2}$

Re Reynolds number

$\mathrm{R}_{\mathrm{P}} \quad$ surface roughness parameter (according to DIN 4762), $\mu \mathrm{m}$

S suppression factor

T temperature, ${ }^{\circ} \mathrm{C}$

W channel width, $\mathrm{m}$

$\mathrm{x} \quad$ vapor quality

\section{Greek}

$\mu \quad$ viscosity, $\mathrm{kg} \mathrm{s}^{-1} \mathrm{~m}^{-1}$

$\rho \quad$ density, $\mathrm{kg} \mathrm{m}^{-3}$

$\sigma \quad$ surface tension, $\mathrm{N} \mathrm{m}^{-1}$

$\Theta \quad$ percentage of predictions which agree with measurements to within $\pm 30 \%$

$\Phi$ ratio of calculated to measured heat transfer coefficient

\section{Subscripts}

calc calculated 


$\begin{array}{ll}\text { conv } & \text { convective } \\ \text { FB } & \text { flow boiling } \\ \mathrm{h} & \text { hydraulic } \\ l & \text { liquid } \\ \text { min } & \text { minimum } \\ \text { meas } & \text { measured } \\ \text { NB } & \text { nucleate boiling } \\ \text { r } & \text { reduced } \\ \text { sat } & \text { saturation } \\ \text { tp } & \text { two-phase } \\ \mathrm{v} & \text { vapor }\end{array}$

\section{Introduction}

Heat transfer in minichannels and microchannels has received significant attention over the last few years, especially for application to electronics cooling [1-6]. While single-phase flow in small channels can easily be described with equations developed for conventional-sized tubes, microchannel flow boiling is significantly affected by the confinement of bubbles [7-10]. Existing heat transfer correlations are unable to accurately predict the flow boiling heat transfer coefficient in small channels over a wide range of operating parameters $[1,4,11]$ as the heat transfer mechanisms are not fully understood. A recent review of the literature [1] showed that a pool boiling correlation [12] outperforms dedicated flow boiling correlations when applied to a large database of results from different research groups for channels of hydraulic diameters smaller than $2 \mathrm{~mm}$. However, even the best predictions showed a mean absolute error (MAE) of $40 \%$ against the large experimental database, and predicted less than half of the measured data to within a deviation of $\pm 30 \%$. It was also noted in [1] that most of the existing minichannel and microchannel heat transfer correlations were developed based on small data sets [13-20]. As a result, these correlations usually performed well in the parameter range over which they were fit, but did not extrapolate well beyond their often narrow operating range [1]. One of the only correlations that was based on a larger set of minichannel and microchannel heat transfer measurements from several independent sources was due to Thome et al. [21, 22]. While this correlation is fairly successful over a broad parameter range, its main drawback lies in its assumption of a single heat transfer regime, which conflicts with the observation of multiple flow regimes by several researchers $[5,23,24,25]$ as well as the trends of several heat transfer measurements $[14,16,19]$. 
In recent years, a large number of well-characterized experiments with small channels have been published [13, 14, 16, 23-37]. These studies cover a wide range of operating parameters, fluids and physical dimensions, and present a good database against which to validate existing correlations and to support the formulation of new correlations.

The aim of the present work is to develop an improved semi-empirical correlation based on the formulation proposed by Chen [38]. The Chen correlation is based on a physical superposition approach and is valid for vapor qualities below 0.7 . The original equation and most later modifications [39-42] were designed for conventional tubes, but nonetheless extrapolate favorably to small channels. Due to its sound physical basis and its independence from specific flow patterns, this approach has been chosen as the basis for the new correlation presented here, and it has been modified to account for the effects of small channel size.

\section{The experimental database}

Table 1 lists data sets on minichannel and microchannel heat transfer measurements from the literature which have been compiled into the database used to develop the composite correlation in the present work. The database consists of 3899 data points from 14 studies in the literature covering 12 different wetting and non-wetting fluids including cryogens and refrigerants.

Hydraulic diameters covered in this database range from $0.16 \mathrm{~mm}$ to $2.92 \mathrm{~mm}$ with corresponding confinement numbers of 0.3 to 4.0 , covering minichannels and microchannels. Data on conventional-sized tubes with lower bubble confinement are not included. The database covers mass fluxes from 20 to $3000 \mathrm{~kg} \mathrm{~m}^{-2} \mathrm{~s}^{-1}$, heat fluxes from 0.4 to $115 \mathrm{~W} \mathrm{~cm}^{-2}$, and saturation temperatures from -194 to $97^{\circ} \mathrm{C}$. The results extend over the complete two-phase range with vapor qualities from 0 to 1 . Round tubes and rectangular channels are included, in arrangements of single tubes and multiple parallel channels. While the channels in most of the studies are oriented in a horizontal direction, three of the studies include data for vertical tubes. Some of the studies included also reported the occurrence of flow instabilities in some of the experiments, while others did not observe any instability in the flow.

\section{Development of the proposed correlation}

Following the basic form of the Chen correlation [38], we start by representing the flow boiling heat transfer coefficient as an addition of weighted nucleate boiling and convective heat transfer terms

$$
\mathrm{h}_{\mathrm{FB}}=\mathrm{h}_{\mathrm{NB}} \cdot \mathrm{S}+\mathrm{h}_{\text {conv, tp }} \cdot \mathrm{F}
$$


where $\mathrm{S}$ is a suppression factor applied to the nucleate boiling term to account for dryout as the vapor quality increases, while the convective heat transfer term is multiplied by factor $\mathrm{F}$ to account for the enhanced convection due to higher flow velocities at increased vapor qualities.

We first choose appropriate equations for the nucleate boiling and the convective heat transfer terms. The Cooper correlation [12] developed for pool boiling is an appropriate choice for $\mathrm{h}_{\mathrm{NB}}$ since it has been shown to provide good predictions of experimental heat transfer coefficients in microchannels [1]. This correlation is given by

$$
\mathrm{h}_{\mathrm{NB}}=55 \cdot \mathrm{P}_{\mathrm{r}}^{0.12-0.2 \cdot \log _{10} \mathrm{R}_{\mathrm{p}}} \cdot\left(-\log _{10} \mathrm{P}_{\mathrm{r}}\right)^{-0.55} \cdot \mathrm{M}^{-0.5} \cdot\left(\mathrm{q}^{\prime \prime}\right)^{0.67} \text {. }
$$

in which it is recommended that the surface roughness measure $R_{P}$ (according to DIN 4762) should be set equal to 1 in cases where the surface roughness is unknown. The convective heat transfer coefficient is calculated as the average of the convective heat transfer coefficients for pure liquid and pure vapor, with a linear dependence on the vapor quality, $\mathrm{x}$ :

$$
\mathrm{h}_{\text {conv, }, \mathrm{p}}=\mathrm{h}_{\text {conv }, l} \cdot(1-\mathrm{x})+\mathrm{h}_{\text {conv }, \mathrm{v}} \cdot \mathrm{x} \text {. }
$$

The Hausen correlation for developing laminar flow [43] is used for convective heat transfer in the liquid and vapor due to the low Reynolds numbers usually encountered in microchannels and their relatively short length in the flow direction. This correlation, for liquid flow, is given by

$$
\mathrm{h}_{\text {conv }, l}=\left(3.66+\frac{0.0668 \cdot \frac{\mathrm{D}_{\mathrm{h}}}{\mathrm{L}} \cdot \mathrm{Re} \cdot \operatorname{Pr}}{1+0.04 \cdot\left[\frac{\mathrm{D}_{\mathrm{h}}}{\mathrm{L}} \cdot \mathrm{Re} \cdot \operatorname{Pr}\right]^{2 / 3}}\right) \cdot \frac{\mathrm{k}_{l}}{\mathrm{D}_{\mathrm{h}}} .
$$

with the vapor-only expression differing only in that properties of saturated vapor are used instead. The Reynolds numbers for saturated liquid and saturated vapor are respectively defined using the total mass flux as

$$
\operatorname{Re}_{l}=\frac{\mathrm{G} \cdot \mathrm{D}_{\mathrm{h}}}{\mu_{l}} \text { and } \quad \operatorname{Re}_{\mathrm{v}}=\frac{\mathrm{G} \cdot \mathrm{D}_{\mathrm{h}}}{\mu_{\mathrm{v}}}
$$

Once the nucleate boiling and convective heat transfer coefficients are calculated, the suppression factor $\mathrm{S}$ and the enhancement factor $\mathrm{F}$ need to be determined. The heat-flux dependence and mass-flux dependence are respectively addressed in the nucleate boiling and the convective heat transfer correlations. The effect of vapor quality, on the other hand, is not represented. Also, the role of channel size and the resulting confinement of bubbles are not accounted for. Both the vapor quality and the confinement of bubbles have been shown to play an important role in determining the heat transfer coefficient in several studies $[1,2,4]$. 
Past formulations of the Chen correlation [38-41] corrected the nucleate boiling term with a suppression factor $\mathrm{S}(\leq 1)$ to account for the suppression of nucleate boiling with an increase in vapor quality which inhibits bubble growth and leads to dryout at high vapor qualities.

Suppression of the bubbles appears to be largely independent of channel diameter $[1,25,31]$. The formulation chosen for the present work assumes a linear decrease of the nucleate boiling heat transfer coefficient with increasing vapor quality

$$
\mathrm{S}=f(\mathrm{x})=1-\mathrm{x},
$$

which is the simplest functional form that still recovers physically correct values at the extremes of vapor quality: in the saturated liquid case $(\mathrm{x}=0)$ pool boiling is not suppressed and in the case of saturated vapor $(\mathrm{x}=1)$ nucleate boiling is absent.

Unlike the suppression factor, the enhancement factor $\mathrm{F}$ is influenced by the confinement of bubbles in small channels, which is the primary reason for the observed differences in the heat transfer for conventional tubes, minichannels and microchannels. In conventional tubes the heat transfer coefficient at high vapor qualities is usually enhanced in the annular flow regime $[38,41$, $42,44]$. For small channels, on the other hand, the enhancement of the heat transfer coefficient with increasing vapor quality is shown to be far smaller $[1,9,23,24,45]$. The enhancement factor must reduce to 1 for pure liquid and pure vapor, and be greater than 1 within the two-phase regime. Therefore the following structure is adopted:

$$
\mathrm{F}=1+f(\operatorname{Co}, \mathrm{x})=1+\mathrm{a} \cdot \mathrm{e}^{-\mathrm{b} \cdot \mathrm{Co}} \cdot\left(\mathrm{x}^{2}-\mathrm{x}^{6}\right) .
$$

A higher confinement number leads to a smaller enhancement factor and the effect of the thermodynamic vapor quality is captured using a polynomial dependence.

Substituting equations (6) and (7) into equation (1) we arrive at the final equation

$$
\mathrm{h}_{\mathrm{FB}}=\mathrm{h}_{\mathrm{NB}} \cdot(1-\mathrm{x})+\mathrm{h}_{\text {conv, tp }} \cdot\left[1+\mathrm{a} \cdot\left(\mathrm{x}^{2}-\mathrm{x}^{6}\right) \cdot \mathrm{e}^{-\mathrm{b} \cdot \mathrm{Co}}\right]
$$

where $\mathrm{a}$ and $\mathrm{b}$ are fitting parameters to be determined from the database of experimental results. Under saturated liquid conditions $(\mathrm{x}=0)$ the liquid convection and pool boiling are simply added, with no enhancement or suppression. At saturated vapor conditions $(x=1)$, pool boiling is absent and the heat transfer coefficient is determined directly by the vapor-only convective heat transfer. Greater confinement leads to a smaller enhancement of the convective heat transfer compared to unconfined flow.

Using the database discussed in section 2, the constants a and b were determined to be 80 and 0.6 , respectively, leading to the following proposed correlation

$$
\mathrm{h}_{\mathrm{FB}}=\mathrm{h}_{\mathrm{NB}} \cdot(1-\mathrm{x})+\mathrm{h}_{\text {conv }, \mathrm{tp}} \cdot\left[1+80 \cdot\left(\mathrm{x}^{2}-\mathrm{x}^{6}\right) \cdot \mathrm{e}^{-0.6 \cdot \mathrm{Co}}\right]
$$


with the nucleate boiling and convective heat transfer coefficients given by equations (2) and (3$5)$.

Figure 1 illustrates the contribution of the different constituent terms to the variation in overall heat transfer coefficient with vapor quality. The contributions of the nucleate boiling and convective heat transfer terms to the total heat transfer coefficient calculated from Eq. (9) as a function of thermodynamic vapor quality are shown. The representative calculations are conducted for refrigerant R-134a at a saturation temperature of $30^{\circ} \mathrm{C}$ in a rectangular channel with a length of $0.2 \mathrm{~m}$ and a channel height-to-width aspect ratio of 1 . The confinement number was set to values of $0.3,1.0$, and 3.0 which lie within the range encountered for minichannels and microchannels, and lead to hydraulic diameters of $2.7,0.8$ and $0.27 \mathrm{~mm}$, respectively. The mass flux in these calculations was set to $300 \mathrm{~kg} \mathrm{~m}^{-2} \mathrm{~s}^{-1}$, while the heat flux was chosen as $10 \mathrm{~W} \mathrm{~cm}^{-2}$ in the top graph and to $3 \mathrm{~W} \mathrm{~cm}^{-2}$ in the bottom graph in Figure 1 .

With the heat flux set at $10 \mathrm{~W} \mathrm{~cm}^{-2}$, the nucleate boiling term decreases linearly with increasing vapor quality, but clearly dominates the convective contribution to heat transfer. The convective heat transfer term becomes significant only at high vapor qualities. The overall heat transfer coefficient decreases steadily but is almost constant over the vapor quality range of 0.2 to 0.6. Similar behavior was found in the experimental data $[16,26,31,33]$. The effect of convection is relatively small and leads to a more pronounced decrease in the overall heat transfer coefficient for the larger confinement numbers (smaller channels).

With a lower heat flux of $3 \mathrm{~W} \mathrm{~cm}^{-2}$, the contributions from nucleate boiling and convective heat transfer are more comparable. In this case the heat transfer coefficient increases slightly at intermediate vapor qualities before dropping sharply towards the onset of dryout at high vapor qualities. This behavior again is consistent with the observations in conventional channels, where the heat transfer increases as the vapor quality increases due to the transition to annular flow, and then drops at the onset of dryout. The convective part of the heat transfer coefficient at a vapor quality of 0 is the largest for the highest confinement. This is due to the increase in convective heat transfer with decreasing hydraulic diameter for a given mass flux.

It is interesting to note that, averaged over the complete database assembled for this work, nucleate boiling accounts for $57 \%$ of the heat transfer while convection accounts for $43 \%$. As the vapor quality decreases, nucleate boiling becomes increasingly significant compared to convective heat transfer. 


\section{Comparison against the experimental database and other correlations}

As a first assessment of the proposed correlation, representative data from four different studies are compared with predictions from the correlation in Figure 2. Figure 2(a) shows data from Bertsch et al. [35] for measurements on R-134a in parallel rectangular channels with an aspect ratio of 2.5 and a hydraulic diameter of $0.54 \mathrm{~mm}$, resulting in a confinement number of 1.7. At low vapor qualities the measured data show an increase in heat transfer coefficient with increasing vapor qualities. At intermediate vapor qualities the transfer coefficient stays nearly level before it drops off at vapor qualities above 0.6. The correlation follows the trend quite well, but slightly underestimates the heat transfer coefficient values, by approximately $15 \%$ on average.

Figure 2(b) considers data from Lee and Lee [14] for flow boiling measurements of R-113 in a single stainless steel channel with a hydraulic diameter of $1.9 \mathrm{~mm}(\mathrm{Co}=0.52)$. The trend of measured heat transfer coefficient versus vapor quality in this case is the opposite of that in Bertsch et al. [35], showing a strong increase in the heat transfer coefficient with increase in vapor quality. At medium and low vapor qualities, the correlation predicts both the trend and magnitudes ( $10 \%$ difference) of heat transfer coefficient well; at high vapor qualities, the predictions drop off somewhat in comparison to the measurements. Most of the heat transfer in this case is determined by convection due to the low confinement number and low heat fluxes.

Measurements from Lin et al. [27] with R-141b in a single, vertical tube of diameter $1 \mathrm{~mm}$ $(\mathrm{Co}=1.06)$ are compared to the predictions in Figure 2(c). At the lowest heat flux, the measured heat transfer coefficient first drops slightly and then increases towards medium vapor qualities. The correlation captures this trend in the case of high heat flux. Overall, it overestimates the magnitudes by approximately 20\%. Finally, Figure 2(d) shows data from Qi et al. [32] for measurements on nitrogen in a single vertical stainless steel tube. The measurements were carried out in tubes of diameter 0.8 to $1.9 \mathrm{~mm}$ resulting in confinement numbers between 1.5 and 0.5. Although the trend of the heat transfer correlation shows a steady decrease in all cases, the absolute values are captured with a deviation of less than $20 \%$.

From these comparisons, it is apparent that the proposed correlation is relatively successful at capturing the major trends in heat transfer coefficient with respect to vapor quality, mass flux, heat flux and bubble confinement from diverse experimental studies.

To provide a global quantitative measure of the performance of the new correlation, two characteristic parameters were evaluated: the mean absolute error defined as

$$
\mathrm{MAE}=\frac{1}{\mathrm{n}} \sum_{\mathrm{n}} \frac{\left\|\mathrm{h}_{\text {calc }}-\mathrm{h}_{\text {meas }}\right\|}{\mathrm{h}_{\text {meas }}}
$$


and $\Theta$, defined as the percentage of predicted data points that agree with the corresponding measured values to within $30 \%$. Using these two measures, the proposed correlation was evaluated against the experimental database and also compared to several other correlations from literature. Many more correlations were compared in an extensive literature review by Bertsch et al. [1] and only the most applicable and the most commonly used correlations are considered here. Table 2 lists all ten correlations along with their appropriate ranges of application. Of these, eight are flow boiling heat transfer correlations while the other two are pool boiling equations that were shown to outperform most of the flow boiling correlations [1]. For data sets where the channel wall roughness was known, the given roughness value was used in all the correlations; otherwise a wall roughness of $1 \mu \mathrm{m}$ was assumed as recommended by Cooper [12].

Table 3 lists the MAE and $\Theta$ for all ten correlations with respect to each data set. The total over all the data sets is included in the last row. Out of all the correlations considered from the literature, Cooper [12] results in the lowest MAE of $39 \%$ and the highest $\Theta$ of $46 \%$. Other correlations that perform well are those of Liu and Winterton [46] and Thome et al. [21, 22]. All other correlations show an MAE of more than 65\%. In comparison, the proposed correlation from the present work shows a $28 \%$ MAE and predicts more than $60 \%$ of the data with an uncertainty of less than $30 \%$. Predictions from the proposed correlation represent all but one of the data sets with MAEs below 50\%. The only exception is the data set from Yun et al. [16], which is also predicted very poorly by all other equations.

The proposed correlation provides good predictions for horizontal and vertical channels, single and parallel arrangements and also for a wide range of heat fluxes and mass fluxes. The effects of channel diameter and confinement are accounted for as well.

As a final comparison to the literature, the ratio

$$
\Phi=\frac{\mathrm{h}_{\text {calc }}}{\mathrm{h}_{\text {meas }}}
$$

was calculated for all the measurements in the experimental database with the correlations listed in Table 2, as well as the proposed correlation. Figure 3 shows semi-logarithmic plots of this ratio for representative correlations chosen for being the most commonly used or for their best agreement with the database. The Bennett and Chen [39] correlation, which was developed for conventional channels and is valid for $\mathrm{x}<0.7$, works best for moderate vapor qualities but tends to overestimate the heat transfer coefficient in small channels. The Kandlikar and Balasubramanian [47] correlation, which was proposed for minichannels and microchannels, shows a far wider spread over the whole vapor quality range. The Liu and Winterton [46] 
correlation improves upon the Chen correlation in that it shows a fairly small deviation similar to the Thome et al. [21, 22] correlation. Clearly the best agreement out of all the correlations in the literature is achieved by the Cooper [12] correlation, which was developed only for pool boiling. The proposed correlation further improves on the low deviation of Cooper and shows very good agreement up to vapor qualities of 0.8. At higher vapor qualities, the trends of several measurements show clearly opposing trends which lead to a slightly larger deviation between some measurements and the correlation.

\section{Conclusions}

A composite heat transfer correlation is proposed for minichannels and microchannels and validated against a database containing 3899 data points from 14 studies in the literature. The new semi-empirical correlation is based on a superposition of nucleate boiling and convection contributions, and shows very good agreement with the magnitudes and trends of variation of the heat transfer coefficient from most data sets with a mean absolute error of $28 \%$. It also predicts over $60 \%$ of the measurements with an uncertainty of less than $\pm 30 \%$, and more than threequarters of the measurements to within $\pm 40 \%$. The proposed correlation is applicable to saturated flow boiling in channels with confinement numbers between 0.3 and 4.0. The correlation covers vertical and horizontal flow, single and multiple parallel channel arrangements, as well as wetting and non-wetting fluids. The effects of heat flux, mass flux, vapor quality and bubble confinement are considered, and the correlation is consistent with physical limits at the extreme values of all its parameters.

The authors acknowledge financial support from members of the Cooling Technologies Research Center, a National Science Foundation Industry/University Cooperative Research Center at Purdue University. 


\section{References}

[1] S. S. Bertsch, E.A. Groll, and S.V. Garimella, 2008, "Review and comparative analysis of studies on saturated flow boiling in small channels," Nanoscale and Microscale Thermophysical Engineering, 12(3), pp. 187 - 227.

[2] C. B. Sobhan, and S.V. Garimella, 2001, "A comparative analysis of studies on heat transfer and fluid flow in microchannels," Microscale Thermophysical Engineering, 5, pp. $293-311$.

[3] G. Hetsroni, D. Klein, A. Mosyak, Z. Segal, and E. Pogrebnyak, 2004, "Convective boiling in parallel microchannels," Microscale Thermophysical Engineering, 8, pp. 403-421.

[4] J. R. Thome, 2004, "Boiling in microchannels: a review of experiment and theory,” Int. J. Heat and Fluid Flow, 25, pp.128-139.

[5] A. Bar-Cohen, and E. Rahim, 2007, "Modeling and prediction of two-phase refrigerant flow regimes and heat transfer characteristics in microgap channels," in proceedings of the 5th International Conference on Nanochannels, Microchannels and Minichannels, ICNMM2007.

[6] S.V. Garimella, V. Singhal and D. Liu, 2006, "On-chip thermal management with microchannel heat sinks and integrated micropumps," Proceedings of the IEEE, 94 (8), pp.1534-1548.

[7] S. V. Garimella, and C. B. Sobhan, 2003, "Transport in microchannels - a critical review," Annual Reviews in Heat Transfer, 13, pp. 1-50.

[8] J. R. Thome, 2006, "State-of-the-art overview of boiling and two-phase flows in microchannels," Heat Transfer Engineering, 27 (9), pp. 4-19.

[9] V. Dupont and J. R. Thome, 2005, "Evaporation in microchannels: influence of the channel diameter on heat transfer," Microfluid Nanofluid, 1, pp.119-127.

[10] C. Vlasie, H. Macchi, J. Guilpart and B. Agostini, 2004, "Flow boiling in small diameter channels," Int. J. Refrigeration, 27, pp. 191-201.

[11] L. Cheng and D. Mewes, 2006, "Review of two-phase flow and flow boiling of mixtures in small and mini channels,” Int. J. Multiphase Flow, 32, pp. 183-207.

[12] M. G. Cooper, 1984, "Heat flow rates in saturated nucleate pool boiling - A wide-ranging examination using reduced properties," Advances in Heat Transfer, 16, pp. 157-239.

[13] Y. Yan and T. Lin, 1998, "Evaporation heat transfer and pressure drop of refrigerant R134a in a small pipe,” Int. J. Heat Mass Transfer, 41, pp. 4183-4194. 
[14] H. J. Lee and S. Y. Lee, 2001, "Heat transfer correlation for boiling flows in small rectangular horizontal channels with low aspect ratios," Int. J. Multiphase Flow, 27, pp. 2043-2062.

[15] J. Lee and I. Mudawar, 2005, "Two-phase flow in high-heat flux micro-channel heat sink for refrigeration cooling applications: Part II - heat transfer characteristics,” Int. J. Heat Mass Transfer, 48, pp. 941-955.

[16] R. Yun, J. H. Heo and Y. Kim, 2006, "Evaporative heat transfer and pressure drop of R410A in microchannels," Int. J. Refrigeration, 29, pp. 92-100.

[17] W. Yu, D. M. France, M. W. Wambsganss and J. R. Hull, 2002, "Two-phase pressure drop, boiling heat transfer, and critical heat flux to water in a small-diameter horizontal tube," Int. J. Multiphase Flow, 28, pp. 927-941.

[18] D. Liu and S. V. Garimella, 2007, "Flow boiling heat transfer in microchannels," J. Heat Transfer, 129 (10), pp 1321-1332.

[19] S. Saitoh, H. Daiguji and E. Hihara, 2007, "Correlation for boiling heat transfer of R-134a in horizontal tubes including effect of tube diameter,' Int. J. Heat Mass Transfer, 50, pp. $5215-5225$.

[20] P. S. Lee and S. V. Garimella, 2008, "Saturated flow boiling heat transfer and pressure drop in silicon microchannel arrays,” Int. J. Heat Mass Transfer, 51 (3-4), pp 789-806.

[21] J. R. Thome, V. Dupont and A. M. Jacobi, 2004, "Heat transfer model for evaporation in microchannels. Part I: presentation of the model,” Int. J. Heat Mass Transfer, 47, pp. 33753385 .

[22] J. R. Thome, V. Dupont and A. M. Jacobi, 2004, "Heat transfer model for evaporation in microchannels. Part II: comparison with the database,” Int. J. Heat Mass Transfer, 47, pp. 3387-3401.

[23] S. S. Bertsch, E. A. Groll and S. V. Garimella, 2008, "Refrigerant flow boiling heat transfer in parallel microchannels as a function of local vapor quality," Int. J. Heat Mass Transfer, 51, pp. 4775-4787.

[24] T. Harirchian and S. V. Garimella, "Microchannel size effects on local flow boiling heat transfer to a dielectric fluid," Int. J. Heat Mass Transfer, 51, pp. 3724-3735.

[25] M. E. Steinke and S. G. Kandlikar, 2004, "An experimental investigation of flow boiling characteristics of water in parallel microchannels," J. Heat Transfer, 126, pp. 518-526.

[26] Z. Y. Bao, D. F. Fletcher and B. S. Haynes, 2000, "Flow boiling heat transfer of freon R11 and HCFC123 in narrow passages,” Int. J. Heat Mass Transfer, 43, pp. 3347-3358. 
[27] S. Lin, P. A. Kew and K. Cornwell, 2001, “Two-phase heat transfer to a refrigerant in a $1 \mathrm{~mm}$ diameter tube,” Int. J. Refrigeration, 24, pp. 51-56.

[28] M. E. Steinke and S. G. Kandlikar, 2004, "An experimental investigation of flow boiling characteristics of water in parallel microchannels," J. Heat Transfer, 126, pp. 518-526.

[29] B. Agostini, A. Bontemps, B. Watel and B. Thonon, 2003, "Boiling heat transfer in minichannels: Influence of the hydraulic diameter," in proceedings of International Congress of Refrigeration 2003, ICR0070.

[30] S. Saitoh, H. Daiguji, and E. Hihara, 2005, "Effect of tube diameter on boiling heat transfer of R-134a in horizontal small-diameter tubes,” Int. J. Heat and Mass Transfer, 48, pp. 4473-4984.

[31] T. N. Tran, M. W. Wambsganss and D. M. France, 1996, "Small circular and rectangularchannel boiling with two refrigerants," Int. J. Multiphase Flow, 22, pp. 485-498.

[32] S. L. Qi, P. Zhang, R. Z. Wang and L. X. Xu, 2007, "Flow boiling of liquid nitrogen in micro-tubes: Part II - Heat transfer characteristics and critical heat flux,” Int. J. Heat Mass Transfer, 50, pp. 5017-5030.

[33] M. W. Wambsganss, D. M. France, J. A. Jendrzejcyk and T. N. Tran, 1993, "Boiling heat transfer in a horizontal small-diameter tube,” J. Heat Transfer, 115, pp. 963-972.

[34] T. Chen and S. V. Garimella, 2006, "Measurements and high-speed visualizations of flow boiling of a dielectric fluid in a silicon microchannel heat sink," Int. J. Multiphase Flow, 32, pp. 957-971.

[35] S. S. Bertsch, E.A. Groll, and S.V. Garimella, 2008, “ Effect of heat flux, mass flux, vapor quality, and saturation temperature on flow boiling heat transfer in microchannels," Int. J. Multiphase Flow, in review.

[36] B. Agostini, J. R. Thome, M. Fabbri, B. Michel, D. Calmi, and U. Kloter, 2008, "High heat flux flow boiling in silicon multi-microchannels: Part I-Heat transfer characteristics of refrigerant R236fa.,” Int. J. Heat Mass Transfer, 51, pp. 5400-5414.

[37] B. Agostini, J. R. Thome, M. Fabbri, B. Michel, D. Calmi, and U. Kloter, 2008, "High heat flux flow boiling in silicon multi-microchannels: Part II-Heat transfer characteristics of refrigerant R245fa.,” Int. J. Heat Mass Transfer, 51, pp. 5415-5425.

[38] J. C. Chen, 1966, "Correlation for boiling heat transfer to saturated fluids in convective flow," I\&EC Process Design and Development, 5 (3), pp. 322-329.

[39] D. L. Bennett and J. C. Chen, 1980, "Forced convective boiling in vertical tubes for saturated pure components and binary mixtures," American Institute of Chemical Engineers Journal, 26 (3), pp. 454-461. 
[40] D.L. Bennett, M.W. Davies, and B.L. Hertzler, 1980, “The suppression of saturated nucleate boiling by forced convective flow," American Institute of Chemical Engineers Symposium Series, 76 (199), pp. 91-103.

[41] S. Edelstein, A. J. Perez and J. C. Chen, 1984, "Analytic representation of convective boiling functions,“ American Institute of Chemical Engineers Journal, 30 (5), pp. 840-841.

[42] W. Zhang, T. Hibiki and K. Mishima, 2004, "Correlation for flow boiling heat transfer in mini-channels,” Int. J. Heat Mass Transfer, 47, pp. 5749-5763.

[43] H. Hausen, 1943, "Darstellung des Wärmeüberganges in Rohren durch verallgemeinerte Potenzbeziehungen,“ Z. VDI Beiheft Verfahrenstechnik, 4, pp. 91-102.

[44] J.R. Thome, 2003, "On recent advances in modeling of two-phase flow and heat transfer," Heat Transfer Engineering, 24 (6), pp. 46-59.

[45] M. W. Wambsganss, D. M. France, J. A. Jendrzejcyk and T. N. Tran, 1993, "Boiling heat transfer in a horizontal small-diameter tube,” J. Heat Transfer, 115, pp. 963-972.

[46] Z. Liu and R. H. S. Winterton, 1991, "A general correlation for saturated and subcooled flow boiling in tubes and annuli, based on a nucleate pool boiling equation," Int. J. Heat Mass Transfer, 34 (11), pp. 2759-2766.

[47] S. G. Kandlikar and P. Balasubramanian, 2004, "An extension of the flow boiling correlation to transition, laminar, and deep laminar flows in minichannel and microchannels," Heat Transfer Engineering, 25 (3), pp. 86-93.

[48] K. E. Gungor and R. H. S. Winterton, 1986, "A general correlation for flow boiling in tubes and annuli,” Int. J. Heat Mass Transfer, 29 (3), pp. 315-358.

[49] G. M. Lazarek and S. H. Black, 1982, "Evaporative heat transfer, pressure drop and critical heat flux in a small vertical tube with R-113," Int. J. Heat Mass Transfer, 25 (7), pp. 945 960.

[50] D. Gorenflo, 1993, "Pool boiling," VDI Heat Atlas, Verein Deutscher Ingenieure, VDIGesellschaft Verfahrenstechnik und Chemieingenieurwesen, ISBN-3184009157. 


\section{List of Tables}

Table 1. Database of studies from which heat transfer coefficients are used in the correlation development.

Table 2. Flow boiling heat transfer correlations considered in this work and their ranges of applicability.

Table 3. Mean absolute error (MAE), and the percentage of predictions $(\Theta)$ which fall within $\pm 30 \%$ of the measurements from each data set.

\section{List of Figure Captions}

Figure 1. Variation with vapor quality of the contributions to the total heat transfer coefficient $\left(\mathrm{h}_{\mathrm{FB}}\right)$ from nucleate boiling $\left(\mathrm{h}_{\mathrm{NB}}\right)$ and convective heat transfer $\left(\mathrm{h}_{\mathrm{conv}, \mathrm{tp}}\right)$; Top: $\mathrm{q} "=10 \mathrm{~W}$ $\mathrm{cm}^{-2}$, Bottom: $\mathrm{q}^{\prime \prime}=3 \mathrm{~W} \mathrm{~cm}^{-2}$ (note the difference in y-axis scale in the two plots).

Figure 2. Comparison between trends in the measurements and those from the proposed correlation for data from (a) Bertsch et al. [35], (b) Lee and Lee [14], (c) Lin et al. [27], and (d) Qi et al. [32].

Figure 3. Ratio of calculated to measured heat transfer coefficient $\Phi$ as a function of thermodynamic quality using correlations proposed by Bennett and Chen [39], Liu and Winterton [46], Thome et al. [21, 22], Kandlikar and Balasubramanian [47], Cooper [12], and the proposed correlation. 
Table 1. Database of studies from which heat transfer coefficients are used in the correlation development.

\begin{tabular}{|c|c|c|c|}
\hline Reference & $\begin{array}{c}\text { Fluid, substrate, orientation, } \\
\text { and geometry }\end{array}$ & $\begin{array}{c}\text { Parameter range } \\
\text { G }\left[\mathrm{kg} \mathrm{m}^{-2} \mathrm{~s}^{-1}\right], \mathrm{q}^{\prime \prime}\left[\mathrm{W} \mathrm{cm}^{-2}\right], \mathrm{P} \\
{[\mathrm{kPa}], \mathrm{T}\left[{ }^{\circ} \mathrm{C}\right]}\end{array}$ & Number of data points \\
\hline $\begin{array}{l}\text { Agostini et al. } \\
\text { [29] }\end{array}$ & $\begin{array}{l}\mathrm{R}-134 \mathrm{a} \text { in aluminum } \\
\text { rectangular }(\mathrm{N}=11,18) \\
\text { vertical } \\
\mathrm{D}_{\mathrm{h}}=0.77,2.01 \mathrm{~mm} \\
\mathrm{~W}_{\min }=0.72,1.47 \mathrm{~mm} \\
\mathrm{Co}=0.5-1.1\end{array}$ & $\begin{array}{l}\mathrm{G}=83-467 \\
\mathrm{q}^{\prime \prime}=0.44-1.5 \\
\mathrm{P}_{\text {sat }}=405-517 \\
\mathrm{x}=0.0-1.0\end{array}$ & $\begin{array}{l}\text { from paper } \\
207 \text { points }\end{array}$ \\
\hline $\begin{array}{l}\text { Agostini et al. } \\
{[36,37]}\end{array}$ & $\begin{array}{l}\text { R236fa and R245fa } \\
\text { Rectangular }(\mathrm{N}=67) \\
\text { Horizontal } \\
\mathrm{D}_{\mathrm{h}}=0.34 \mathrm{~mm} \\
\mathrm{~W}_{\min }=0.22 \mathrm{~mm} \\
\mathrm{Co}=2.9\end{array}$ & $\begin{array}{l}\mathrm{G}=281-1501 \\
\mathrm{q}^{\prime \prime}=0.7-42 \\
\mathrm{x}=0.02-0.78 \\
\mathrm{P}_{\text {sat }}=141-273 \\
\mathrm{~T}_{\text {sat }}=25-43\end{array}$ & $\begin{array}{l}\text { from paper } \\
1392 \text { points }\end{array}$ \\
\hline Bao et al. [26] & $\begin{array}{l}\mathrm{R} 11, \mathrm{R} 123 \text { in copper } \\
\text { circular }(\mathrm{N}=1) \\
\text { horizontal } \\
\mathrm{D}=1.95 \\
\mathrm{Co}=0.4-0.5\end{array}$ & $\begin{array}{l}\mathrm{G}=50-1800 \\
\mathrm{q}^{\prime \prime}=0.5-20 \\
\mathrm{P}=200-500 \\
\mathrm{x}=0.0-0.9\end{array}$ & $\begin{array}{l}\text { from paper } \\
166 \text { points }\end{array}$ \\
\hline $\begin{array}{l}\text { Bertsch et al. [23, } \\
35]\end{array}$ & $\begin{array}{l}\mathrm{R} 134 \mathrm{a}, \mathrm{R} 245 \mathrm{fa} \text { in copper } \\
\text { rectangular }(\mathrm{N}=17,33) \\
\text { horizontal } \\
\mathrm{D}_{\mathrm{h}}=0.54,1.09 \mathrm{~mm} \\
\mathrm{~W}_{\min }=0.38,0.76 \mathrm{~mm} \\
\mathrm{Co}=0.7-1.9\end{array}$ & $\begin{array}{l}\mathrm{G}=20-350 \\
\mathrm{q}^{\prime \prime}=5-22 \\
\mathrm{~T}_{\text {sat }}=8-30 \\
\mathrm{x}=0-0.95\end{array}$ & $\begin{array}{l}\text { original data set } \\
332 \text { points }\end{array}$ \\
\hline $\begin{array}{l}\text { Chen and } \\
\text { Garimella [34] }\end{array}$ & $\begin{array}{l}\text { FC-77 in copper and silicon } \\
\text { rectangular }(\mathrm{N}=10,24) \\
\text { horizontal } \\
\mathrm{D}_{\mathrm{h}}=0.84,0.39 \mathrm{~mm} \\
\mathrm{~W}_{\min }=0.38,0.54 \mathrm{~mm} \\
\mathrm{Co}=0.8-1.6\end{array}$ & $\begin{array}{l}\mathrm{G}=63.5-440 \\
\mathrm{q}^{\prime \prime}=2-80 \\
\mathrm{~T}_{\text {sat }}=97 \\
\mathrm{x}=0.01-0.99\end{array}$ & $\begin{array}{l}\text { original data set } \\
115 \text { points }\end{array}$ \\
\hline $\begin{array}{l}\text { Harirchian and } \\
\text { Garimella [24] }\end{array}$ & $\begin{array}{l}\text { FC-77 in silicon } \\
\text { rectangular }(\mathrm{N}=2-60) \\
\text { horizontal } \\
\mathrm{D}_{\mathrm{h}}=0.16-0.57 \mathrm{~mm} \\
\mathrm{~W}_{\min }=0.1-0.4 \mathrm{~mm} \\
\mathrm{Co}=0.8-4.0\end{array}$ & $\begin{array}{l}\mathrm{G}=250-1600 \\
\mathrm{q}^{\prime \prime}=0-30 \\
\mathrm{~T}_{\text {sat }}=90-93 \\
\mathrm{x}=0-1\end{array}$ & $\begin{array}{l}\text { original data set } \\
327 \text { points }\end{array}$ \\
\hline Lee and Lee [14] & $\begin{array}{l}\mathrm{R} 113 \text { in stainless steel } \\
\text { rectangular }(\mathrm{N}=1) \\
\text { horizontal } \\
\mathrm{D}_{\mathrm{h}}=0.78-3.63 \mathrm{~mm} \\
\mathrm{~W}_{\min }=0.4-2.0 \mathrm{~mm} \\
\mathrm{Co}=0.3-1.3\end{array}$ & $\begin{array}{l}\mathrm{G}=50-200 \\
\mathrm{q}^{\prime \prime}=0.0-1.5 \\
\mathrm{x}=0.15-0.75 \\
\mathrm{P}_{\text {sat }}=100\end{array}$ & $\begin{array}{l}\text { from paper } \\
553 \text { points }\end{array}$ \\
\hline Lin et al. [27] & $\begin{array}{l}\text { Water and R-141b } \\
\text { circular }(\mathrm{N}=1) \\
\text { vertical } \\
\mathrm{D}=1 \mathrm{~mm} \\
\mathrm{Co}=1.1\end{array}$ & $\begin{array}{l}\mathrm{G}=300-2000 \\
\mathrm{q}^{\prime \prime}=1-115 \\
\mathrm{~T}_{\text {sat }}=39-56 \\
\mathrm{x}=0-1\end{array}$ & $\begin{array}{l}\text { from paper } \\
133 \text { points }\end{array}$ \\
\hline
\end{tabular}




\begin{tabular}{|c|c|c|c|}
\hline Reference & $\begin{array}{c}\text { Fluid, substrate, orientation, } \\
\text { and geometry }\end{array}$ & $\begin{array}{c}\text { Parameter range } \\
\mathrm{G}\left[\mathrm{kg} \mathrm{m}^{-2} \mathrm{~s}^{-1}\right], \mathrm{q}^{\prime \prime}\left[\mathrm{W} \mathrm{cm}^{-2}\right], \mathrm{P} \\
{[\mathrm{kPa}], \mathbf{T}\left[{ }^{\circ} \mathrm{C}\right]}\end{array}$ & Number of data points \\
\hline$\overline{\text { Qi et al. [32] }}$ & $\begin{array}{l}\text { Nitrogen in stainless } \\
\text { circular }(\mathrm{N}=1) \\
\text { vertical } \\
\mathrm{D}=0.53-1.93 \mathrm{~mm} \\
\mathrm{Co}=0.5-1.6\end{array}$ & $\begin{array}{l}\mathrm{G}=440-3000 \\
\mathrm{q}^{\prime \prime}=5-21 \\
\mathrm{~T}_{\text {sat }}=-194 \\
\mathrm{x}=0-0.9\end{array}$ & $\begin{array}{l}\text { from paper } \\
181 \text { points }\end{array}$ \\
\hline Saitoh et al. [30] & $\begin{array}{l}\mathrm{R}-134 \mathrm{a} \\
\text { circular }(\mathrm{N}=1) \\
\text { horizontal } \\
\mathrm{D}=0.51,1.12,3.1 \mathrm{~mm} \\
\mathrm{Co}=0.3-1.8\end{array}$ & $\begin{array}{l}\mathrm{G}=150-450 \\
\mathrm{q}^{\prime \prime}=0.5-3.9 \\
\mathrm{~T}_{\text {ata }}=5-15 \\
\mathrm{x}=0.0-1.0\end{array}$ & $\begin{array}{l}\text { from paper } \\
164 \text { points }\end{array}$ \\
\hline Tran et al. [31] & $\begin{array}{l}\mathrm{R} 12 \text { in brass } \\
\text { circular }(\mathrm{N}=1) \\
\text { horizontal } \\
\mathrm{D}=2.46 \mathrm{~mm} \\
\mathrm{Co}=0.3\end{array}$ & $\begin{array}{l}\mathrm{G}=89-300 \\
\mathrm{q}^{\prime \prime}=0.7-5.9 \\
\mathrm{x}=0.2-0.8 \\
\mathrm{P}_{\text {sat }}=825\end{array}$ & $\begin{array}{l}\text { from paper } \\
62 \text { points }\end{array}$ \\
\hline $\begin{array}{l}\text { Wambsganss et } \\
\text { al. [33] }\end{array}$ & $\begin{array}{l}\text { R113 in copper } \\
\text { circular }(\mathrm{N}=1) \\
\text { horizontal } \\
\mathrm{D}=2.92 \mathrm{~mm} \\
\mathrm{Co}=0.3\end{array}$ & $\begin{array}{l}\mathrm{G}=50-300 \\
\mathrm{q}^{\prime \prime}=0.9-9.1 \\
\mathrm{x}=0-0.9\end{array}$ & $\begin{array}{l}\text { from paper } \\
92 \text { points }\end{array}$ \\
\hline Yan and Lin [13] & $\begin{array}{l}\text { R-134a in copper } \\
\text { circular, }(\mathrm{N}=28) \\
\text { horizontal } \\
\mathrm{D}=2.0 \mathrm{~mm} \\
\mathrm{Co}=0.4-0.5\end{array}$ & $\begin{array}{l}\mathrm{G}=50-200 \\
\mathrm{q}^{\prime \prime}=0.5-2.0 \\
\mathrm{~T}_{\text {sat }}=5-31 \\
\mathrm{x}=0.05-0.85\end{array}$ & $\begin{array}{l}\text { from paper } \\
133 \text { points }\end{array}$ \\
\hline Yun et al. [16] & $\begin{array}{l}\mathrm{R} 410 \mathrm{~A} \text { in aluminum } \\
\text { rectangular }(\mathrm{N}=7,8) \\
\text { horizontal } \\
\mathrm{D}_{\mathrm{h}}=1.36,1.44 \mathrm{~mm} \\
\mathrm{~W}_{\min }=1.2 \mathrm{~mm} \\
\mathrm{Co}=0.6\end{array}$ & $\begin{array}{l}\mathrm{G}=200-400 \\
\mathrm{q}^{\prime \prime}=1-2 \\
\mathrm{~T}_{\text {sat }}=0,5,10 \\
\mathrm{x}=0.0-0.85\end{array}$ & $\begin{array}{l}\text { from paper } \\
101 \text { points }\end{array}$ \\
\hline$\overline{\text { Total }}$ & $\begin{array}{l}12 \text { fluids } \\
D_{h}=0.16-2.92 \mathrm{~mm} \\
W_{\min }=0.1-2.92 \mathrm{~mm} \\
C o=0.3-4.0\end{array}$ & $\begin{array}{l}G=20-3000 \\
q^{\prime \prime}=0.4-115 \\
T_{\text {sat }}=-194-97 \\
x=0-1\end{array}$ & $\begin{array}{l}14 \text { data sets } \\
3899 \text { points }\end{array}$ \\
\hline
\end{tabular}


Table 2. Flow boiling heat transfer correlations considered in this work and their ranges of applicability.

\begin{tabular}{|c|c|c|}
\hline Reference & $\begin{array}{l}\text { Fluid, } \\
\text { Channel Geometry }\end{array}$ & $\begin{array}{c}\text { Parameter Range } \\
\mathbf{G}\left[\mathrm{kg} \mathrm{m}^{-2} \mathrm{~s}^{-1}\right], \mathbf{q}^{\prime \prime}\left[\mathrm{W} \mathrm{cm} \mathbf{~ c m}^{-2}\right], \\
\mathbf{P}[\mathrm{kPa}]\end{array}$ \\
\hline $\begin{array}{l}\text { Bennett and Chen (1980) [39] } \\
\text { Bennett et al. (1980) [40] }\end{array}$ & $\begin{array}{l}\text { Water, Methanol, Pentane, Heptane, } \\
\text { Benzene,... }\end{array}$ & $\begin{array}{l}P=55-3500 \\
q^{\prime \prime}=0.6-240 \\
x=0.01-0.71\end{array}$ \\
\hline $\begin{array}{l}\text { Gungor and Winterton (1986) } \\
{[48]}\end{array}$ & $\begin{array}{l}\text { Water, R11, R12, R113,... } \\
\mathrm{D}_{\mathrm{h}}=2.95-32.0 \mathrm{~mm}\end{array}$ & $\begin{array}{l}\mathrm{G}=67-61518 \\
\mathrm{q}^{\prime \prime}=0.11-228 \\
\mathrm{x}=0.0-1.0\end{array}$ \\
\hline $\begin{array}{l}\text { Kandlikar and Balasubramanian (2004) } \\
\text { [47] }\end{array}$ & $\begin{array}{l}\text { Water, R113, R123, R141b, .. } \\
\mathrm{D}_{\mathrm{h}}=0.19-2.92 \mathrm{~mm}\end{array}$ & $\begin{array}{l}\mathrm{G}=50-570 \\
\mathrm{q}^{\prime \prime}=0.5-9.1 \\
\mathrm{x}=0.00-0.98\end{array}$ \\
\hline Lazarek and Black (1982) [49] & $\begin{array}{l}\mathrm{R} 113 \\
\mathrm{D}_{\mathrm{h}}=3.1 \mathrm{~mm}\end{array}$ & $\begin{array}{l}\mathrm{G}=125-750 \\
\mathrm{q}=1.4-38 \\
\mathrm{x}=0.0-0.6\end{array}$ \\
\hline $\begin{array}{l}\text { Liu and Garimella (2007) } \\
\text { [18] }\end{array}$ & $\begin{array}{l}\text { Water; } \\
\mathrm{D}_{\mathrm{h}}=0.38,0.59 \mathrm{~mm}\end{array}$ & $\begin{array}{l}\mathrm{G}=221-283 \\
\mathrm{q}^{\prime \prime}=0-129 \\
\mathrm{x}=0-0.2\end{array}$ \\
\hline $\begin{array}{l}\text { Liu and Winterton (1991) } \\
\text { [46] }\end{array}$ & $\begin{array}{l}\text { Water and refrigerants } \\
\mathrm{D}_{\mathrm{h}}=2.95-32.0 \mathrm{~mm}\end{array}$ & $\begin{array}{l}\mathrm{G}=12.4-8157 \\
\mathrm{q}^{\prime \prime}=0.35-262 \\
\mathrm{x}=0.0-0.95\end{array}$ \\
\hline $\begin{array}{l}\text { Saitoh et al. (2007) } \\
\text { [19] }\end{array}$ & $\begin{array}{l}\mathrm{R} 134 \mathrm{a} \\
\mathrm{D}_{\mathrm{h}}=0.5-11.0 \mathrm{~mm}\end{array}$ & \\
\hline $\begin{array}{l}\text { Thome et al. (2004) } \\
{[21,22]} \\
\text { Agostini et al. (2008) [37] }\end{array}$ & $\begin{array}{l}\text { R11, R12, R113, R123, R134a, R141b, } \\
\mathrm{CO}_{2}, \mathrm{R} 245 \mathrm{fa}, \mathrm{R} 236 \mathrm{fa} \\
\mathrm{D}_{\mathrm{h}}=0.7-3.1 \mathrm{~mm}\end{array}$ & $\begin{array}{l}\mathrm{G}=50-502 \\
\mathrm{q}^{\prime \prime}=0.5-17.8 \\
\mathrm{x}=0.01-0.99\end{array}$ \\
\hline $\begin{array}{l}\text { Cooper (pool boiling) (1984) } \\
\text { [12] }\end{array}$ & $\begin{array}{l}\text { Water, refrigerants, organic fluids, } \\
\text { cryogens }\end{array}$ & $\mathrm{q}^{\prime \prime}=0.01-60$ \\
\hline $\begin{array}{l}\text { Gorenflo (pool boiling) (1993) } \\
{[50]}\end{array}$ & $\begin{array}{l}\text { Several refrigerants, water and } \\
\text { cryogenics }\end{array}$ & $\mathrm{q}^{\prime \prime}=0-30$ \\
\hline
\end{tabular}


Table 3. Mean absolute error (MAE), and the percentage of predictions $(\Theta)$ which fall within $\pm 30 \%$ of the measurements from each data set.

\begin{tabular}{|c|c|c|c|c|c|c|c|c|c|c|c|}
\hline $\begin{array}{l}\text { Correlation } \rightarrow \\
\downarrow \text { Database }\end{array}$ & $\begin{array}{c}\text { Bennett and } \\
\text { Chen [39] }\end{array}$ & $\begin{array}{c}\text { Gungor and } \\
\text { Winterton } \\
{[48]}\end{array}$ & $\begin{array}{c}\text { Kandlikar } \\
\text { and Balasub- } \\
\text { ramanian } \\
{[47]}\end{array}$ & $\begin{array}{c}\text { Lazarek and } \\
\text { Black [49] }\end{array}$ & $\begin{array}{c}\text { Liu and } \\
\text { Garimella } \\
\text { [18] }\end{array}$ & $\begin{array}{c}\text { Liu and } \\
\text { Winterton } \\
{[46]}\end{array}$ & $\begin{array}{c}\text { Saitoh et al. } \\
\text { [19] }\end{array}$ & $\begin{array}{c}\text { Thome et al. } \\
{[21,22]}\end{array}$ & $\begin{array}{c}\text { Cooper } \\
\text { [12] }\end{array}$ & $\begin{array}{c}\text { Gorenflo } \\
\text { [50] }\end{array}$ & $\begin{array}{l}\text { Proposed } \\
\text { new } \\
\text { correlation }\end{array}$ \\
\hline \multirow{2}{*}{$\begin{array}{c}\text { Agostini et al. } \\
{[29]} \\
\end{array}$} & $\mathrm{MAE}=81$ & 48 & 47 & 60 & 60 & 59 & 58 & 51 & 61 & 59 & 50 \\
\hline & $\Theta=16$ & 43 & 27 & 11 & 9 & 10 & 12 & 22 & 10 & 11 & 18 \\
\hline \multirow{2}{*}{$\begin{array}{c}\text { Agostini et al. } \\
{[36,37]}\end{array}$} & 48 & 98 & 43 & 33 & 52 & 34 & 26 & 37 & 44 & 26 & 29 \\
\hline & 48 & 11 & 23 & 59 & 41 & 47 & 72 & 28 & 13 & 70 & 48 \\
\hline \multirow{2}{*}{ Bao et al. [26] } & 37 & 33 & 40 & 8 & 78 & 31 & 13 & 12 & 23 & 14 & 33 \\
\hline & 30 & 45 & 40 & 100 & 4 & 38 & 99 & 93 & 93 & 98 & 39 \\
\hline \multirow{2}{*}{$\begin{array}{c}\text { Bertsch et al. } \\
{[24,35]}\end{array}$} & 63 & 158 & 93 & 61 & 60 & 34 & 57 & 84 & 27 & 70 & 15 \\
\hline & 52 & 4 & 23 & 34 & 13 & 65 & 36 & 30 & 72 & 24 & 92 \\
\hline \multirow{2}{*}{$\begin{array}{c}\text { Chen and } \\
\text { Garimella [34] }\end{array}$} & 65 & 443 & 111 & 61 & 69 & 30 & 143 & 48 & 28 & 116 & 44 \\
\hline & 3 & 1 & 31 & 7 & 13 & 36 & 0 & 30 & 41 & 1 & 23 \\
\hline \multirow{2}{*}{$\begin{array}{l}\text { Harirchian and } \\
\text { Garimella [24] }\end{array}$} & 190 & 475 & 105 & 151 & 132 & 77 & 214 & 45 & 8 & 157 & 18 \\
\hline & 2 & 0 & 29 & 0 & 24 & 30 & 0 & 38 & 98 & 0 & 81 \\
\hline \multirow{2}{*}{$\begin{array}{c}\text { Lee and Lee } \\
{[14]}\end{array}$} & 41 & 25 & 39 & 61 & 31 & 34 & 31 & 67 & 61 & 56 & 19 \\
\hline & 34 & 66 & 39 & 3 & 52 & 45 & 53 & 2 & 4 & 12 & 77 \\
\hline \multirow{2}{*}{ Lin et al. [27] } & 305 & 263 & 16 & 74 & 80 & 128 & 135 & 20 & 38 & 39 & 47 \\
\hline & 2 & 0 & 95 & 7 & 28 & 5 & 4 & 83 & 43 & 41 & 24 \\
\hline \multirow{2}{*}{ Qi et al. [32] } & 74 & 151 & 90 & 189 & 71 & 37 & 54 & 55 & 38 & 26 & 29 \\
\hline & 35 & 6 & 22 & 2 & 1 & 50 & 45 & 14 & 50 & 61 & 63 \\
\hline \multirow{2}{*}{$\begin{array}{c}\text { Saitoh et al. } \\
{[30]}\end{array}$} & 158 & 107 & 55 & 47 & 55 & 37 & 43 & 45 & 53 & 50 & 34 \\
\hline & 24 & 29 & 50 & 53 & 30 & 53 & 74 & 36 & 13 & 29 & 51 \\
\hline \multirow{2}{*}{ Tran et al. [31] } & 25 & 22 & 63 & 27 & 52 & 29 & 9 & 7 & 20 & 11 & 22 \\
\hline & 65 & 68 & 5 & 60 & 32 & 56 & 100 & 100 & 97 & 100 & 69 \\
\hline \multirow{2}{*}{$\begin{array}{c}\text { Wambsganss et } \\
\text { al. [33] }\end{array}$} & 50 & 73 & 46 & 14 & 36 & 27 & 25 & 16 & 16 & 24 & 20 \\
\hline & 39 & 13 & 21 & 88 & 42 & 74 & 62 & 92 & 91 & 65 & 82 \\
\hline \multirow{2}{*}{$\begin{array}{c}\text { Yan and Lin } \\
{[13]} \\
\end{array}$} & 52 & 44 & 54 & 33 & 40 & 31 & 24 & 41 & 33 & 31 & 27 \\
\hline & 40 & 47 & 5 & 42 & 37 & 50 & 76 & 59 & 44 & 59 & 60 \\
\hline \multirow{2}{*}{ Yun et al. [16] } & 49 & 38 & 76 & 64 & 78 & 68 & 59 & 46 & 70 & 68 & 64 \\
\hline & 8 & 26 & 0 & 0 & 0 & 0 & 0 & 16 & 0 & 0 & 0 \\
\hline \multirow{2}{*}{ Total } & $M A E=88$ & 149 & 66 & 74 & 65 & 46 & 71 & 51 & 39 & 65 & 28 \\
\hline & $\Theta=27$ & 29 & 31 & 24 & 25 & 41 & 41 & 35 & 46 & 29 & 61 \\
\hline
\end{tabular}

$*$ The two numbers for each correlation represent MAE the mean absolute error and $\Theta$ the percentage of predictions which fall within $\pm 30 \%$ of the measurements. Numbers in bold indicate MAE below $20 \%$, or more than $60 \%$ of the data predicted within $\pm 30 \%$ of the measurement. 



Figure 1. Variation with vapor quality of the contributions to the total heat transfer coefficient $\left(\mathrm{h}_{\mathrm{FB}}\right)$ from nucleate boiling $\left(\mathrm{h}_{\mathrm{NB}}\right)$ and convective heat transfer $\left(\mathrm{h}_{\mathrm{conv}, \mathrm{tp}}\right)$; Top: $\mathrm{q} "=10 \mathrm{~W} \mathrm{\textrm {cm } ^ { - 2 }}$, Bottom: $\mathrm{q}^{\prime \prime}=3 \mathrm{~W} \mathrm{~cm}^{-2}$ (note the difference in y-axis scale in the two plots). 

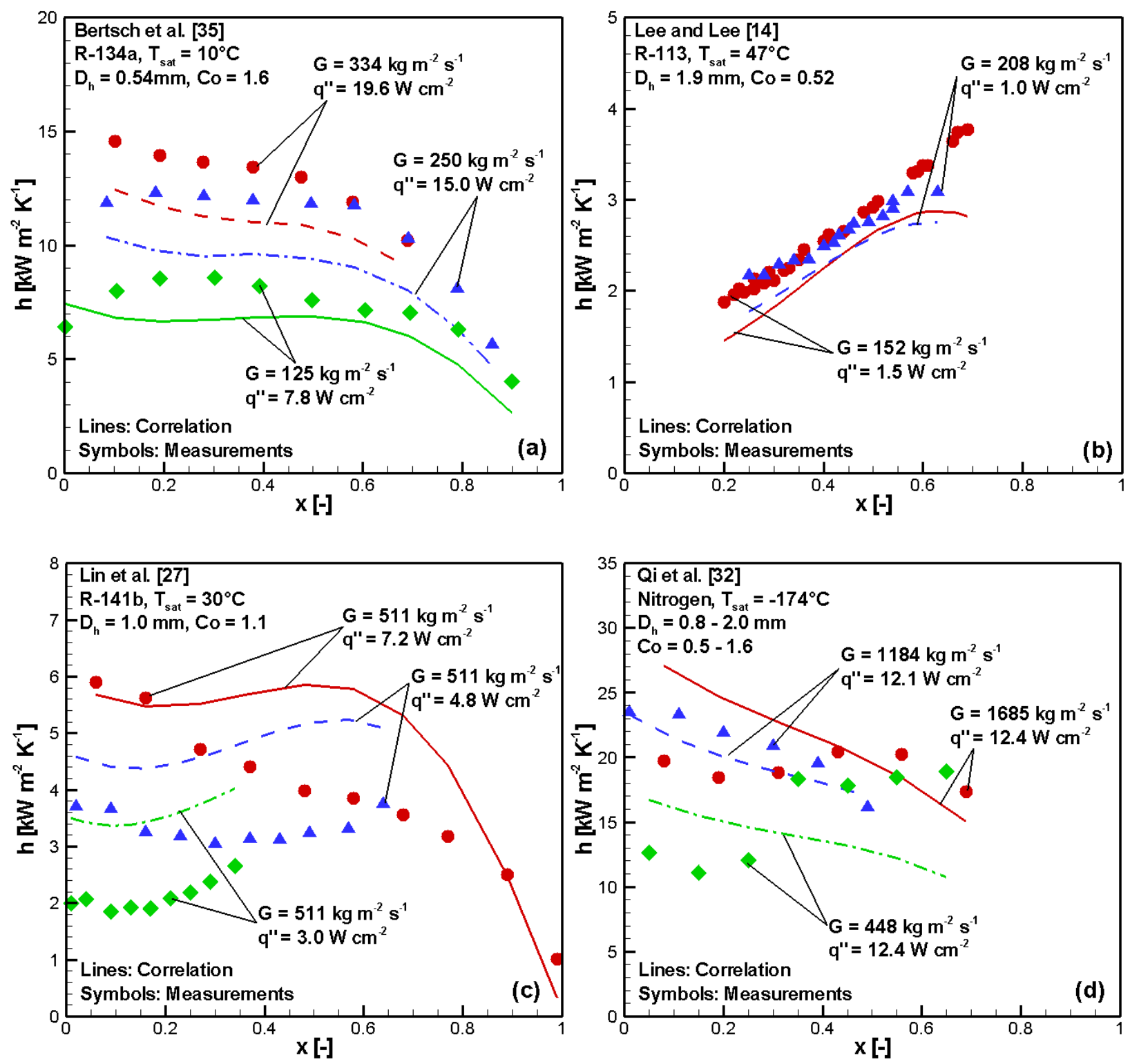

Figure 2: Comparison between trends in the measurements and those from the proposed correlation for data from (a) Bertsch et al. [35], (b) Lee and Lee [14], (c) Lin et al. [27], and (d) Qi et al. [32]. 

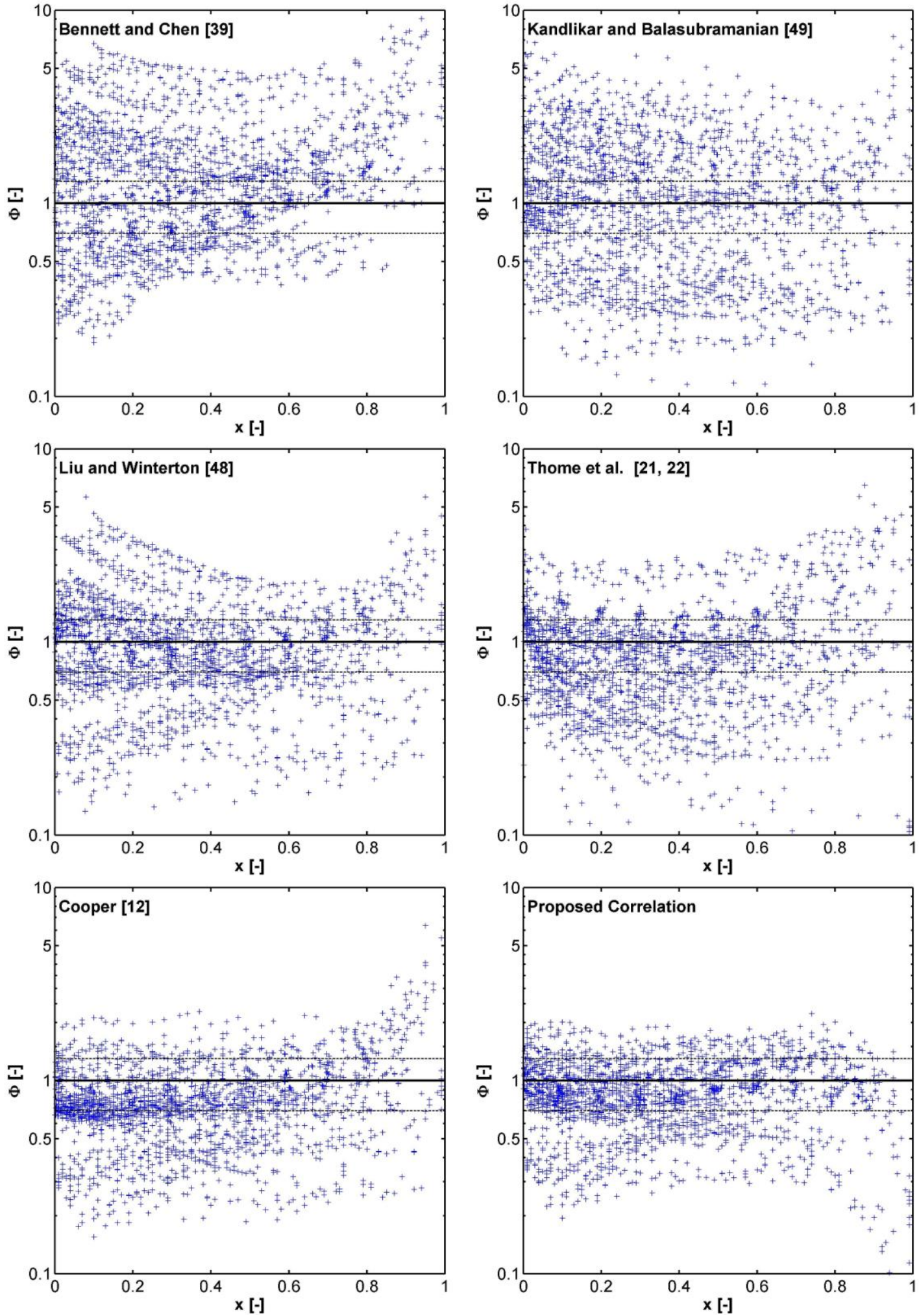

Figure 3. Ratio of calculated to measured heat transfer coefficient $\Phi$ as a function of thermodynamic quality using correlations proposed by Bennett and Chen [39], Liu and Winterton [46], Thome et al. [21, 22], Kandlikar and Balasubramanian [47], Cooper [12], and the proposed correlation. 